\begin{abstract}
Ammonia has great prospects in the context of the transition to carbon-free energy. It can be used as fuel in gas turbines, fuel cells, internal combustion engines, and burned together with coal. However, industrial production of ammonia is based on the Haber-Bosh process, which involves the use of natural gas and coal, which, in this case, does not make it really carbon-free. This study proposes a method to produce ammonia, which is environmentally friendly and does not require the use of fossil fuels. It is based on the approach to adjusting the concentration of ammonium nitrogen in a biogas reactor and implies the sorption of ammonia from the gas phase with a solution of monoammonium phosphate, obtaining diammonium phosphate, and subsequently heating it with the release of ammonia. The factors influencing the extraction of ammonia from waste have been considered, as well as the influence of temperature on the release of ammonia from the solution of diammonium phosphate; the energy efficiency of the method has been assessed. With increasing temperature, the degree of ammonia and the degree of sorbent regeneration increased. Under laboratory conditions, $111 \mathrm{~J} / \mathrm{g}$ of ammonia energy was spent. The higher the concentration of $\left(\mathrm{NH}_{4}\right)_{2} \mathrm{HPO}_{4}$ in the solution, the less energy is required to obtain a unit of ammonia mass. The total amount of ammonia released varies depending on the temperature. Sorbent regeneration can be carried out using thermal energy obtained at a cogeneration plant. The possibility of using this method to produce ammonia at an industrial scale has been estimated by analyzing the ways of ammonia utilization as a fuel. The potential for ammonia production in the main livestock industries in Europe and the United States is up to 11,482,651.15 and 11,582,169.5 tons per year, respectively. Applying this solution also makes it possible to improve the efficiency of biogas production from waste with high nitrogen content. The proposed method of ammonia production could potentially contribute to the development of carbon-free energy

Keywords: ammonia production, carbon-free energy, anaerobic digestion, ammonium nitrogen, ammonium phosphates
\end{abstract}

\section{DEVELOPMENT OF AN AMMONIA PRODUCTION METHOD FOR CARBON-FREE ENERGY GENERATION}

\author{
Sergey Zhadan \\ $\mathrm{PhD}$, Engineer Researcher \\ Individual Entrepreneur «A.O. Dyba» \\ Kudryashova str., 7-B, Kyiv, Ukraine, 03035 \\ Yevhenii Shapovalov \\ Corresponding author \\ $\mathrm{PhD}$, Senior Researcher \\ Department of Knowledge Systems Creation \\ Junior Academy of Sciences of Ukraine \\ Degtyarivska str., 38/44, Kyiv, Ukraine, 04119 \\ E-mail: sjb@man.gov.ua \\ Roman Tarasenko \\ Postgraduate Student \\ Institute of Telecommunications \\ and Global Information Space \\ Chokolivskyi blvd., 13, Kyiv, Ukraine, 03186 \\ Anatoliy Salyuk \\ $\mathrm{PhD}$, Professor \\ Department of Food Chemistry \\ National University of Food Technologies \\ Volodymyrska str., 68, Kyiv, Ukraine, 01601
}

Received date 11.08.2021 Accepted date 17.10.2021 Published date 29.10.2021
How to Cite: Zhadan, S., Shapovalov, Y., Tarasenko, R., Salyuk, A. (2021). Development of an ammonia production method for carbon-free energy generation. Eastern-European Journal of Enterprise Technologies, 5 (8 (113)), 66-75. doi: https://doi.org/ 10.15587/1729-4061.2021.243068

\section{Introduction}

Much attention around the world is directed at reducing $\mathrm{CO}_{2}$ emissions to prevent the negative effects of global warming. The European Union has decided to reduce greenhouse gas emissions by at least $55 \%$ by 2030 compared to 1990 levels [1,2]. In 2019, the European Commission announced plans to adjust the EU economic course to create a climate and carbon-neutral space in Europe by 2050 [3, 4].

Most countries have set targets for future reductions in greenhouse gas emissions. For example, the Japanese government has identified national (INDC) contributions at a $26.0 \%$ reduction in greenhouse gas emissions by the fiscal year 2030 compared to the fiscal year 2013 [5]. The Japanese government has also set a long-term goal of reducing greenhouse gas emissions by $80 \%$ by the fiscal year of 2050 [6]. Germany plans to reduce greenhouse gas emissions by $80-95 \%$ by 2050 [7]; the United Kingdom - by $80 \%$ [8]; Japan, France, and Canada - by 73-78 \%; and Russia - by $48 \%$ [9].

The UN estimates that cities account for up to $70 \%$ of global anthropogenic greenhouse gas emissions [10]. In this regard, more than 100 cities announced their intention to become carbon neutral by 2050 . Some of them want to achieve the goal earlier: Stockholm by 2040, Copenhagen by 2025, and Liverpool by 2020 [8].

American Apple Inc. has announced a goal to reduce total carbon dioxide emissions to zero across the entire supply and production chain by 2030. Microsoft Corp. has announced that it intends to achieve negative emissions by 2030, and, by 2050 , to completely eliminate the effects of carbon dioxide emissions over the entire time since the company was founded in 1975 [11]

The reduction of $\mathrm{CO}_{2}$ emissions into the atmosphere is associated with the transition to carbon-free energy. This 
includes the use of fuels such as hydrogen and ammonia [12]. Using the latter has a series of critical advantages. However, the disadvantage of ammonia is greenhouse gas emissions in its production. In order for the use of ammonia to become a truly carbon-free solution, it is necessary to develop a method of its production that does not involve the use of fossil fuels.

\section{Literature review and problem statement}

The production of ammonia is carried out through the so-called Haber-Bosh process [12], which was invented by German chemist and Nobel Prize winner Fritz Haber in the early $20^{\text {th }}$ century [13]. The process is based on the synthesis of ammonia from nitrogen and hydrogen at temperatures of $380-450{ }^{\circ} \mathrm{C}$ and a pressure of $250 \mathrm{~atm}$ using an iron catalyst [14].

The use of the Haber-Bosh process has a negative impact on the environment. For its implementation, hydrogen is required, which is removed from natural gas or coal as a result of a reaction using compressed overheated steam. At the same time, carbon dioxide is formed, which is about half the emissions of the general process. The second raw material, nitrogen, is easily separated from the air, which is $78 \%$ of it. However, creating the pressure required to merge hydrogen and nitrogen into reactors consumes more fossil fuels, which means more carbon dioxide is generated [15]. A large amount of ammonia produced in this way worldwide (more than 235 million tons) causes $1-2 \%$ of world energy consumption and causes about 450 million tons of $\mathrm{CO}_{2}$ emissions per year. This is approximately $1 \%$ of all anthropogenic emissions and more than any other industrial chemical reaction [13]. The reason for this may be objective difficulties associated with the lack of alternatives to production, and optimizing the Haber-Bosh process will not solve the problem fundamentally, which makes conducting such research impractical.

An option to overcome the corresponding difficulties may be to obtain ammonia from waste during their decomposition. Studies on the anaerobic digestion (AD) of poultry waste [16] report that a high nitrogen content often causes problems associated with its toxicity to anaerobic microorganisms. Nitrogen extraction and conversion into a form of ammonia could ensure both the production of a useful product and ensure intensification of the process of anaerobic processing of livestock products. Previously, no such approach was proposed. For example, work [17] used sulfate acid, sorption of which led to the formation of ammonium sulfates and, in [18], iron-containing clay. Other methods included removal with air [19], nitrogen [20], vacuum [21], biogas recirculation, and nitrogen extraction by acid sorption [21], or adding minerals [22]. The use of sulfate acid and the proposed technology for obtaining a decrease in ammonia content did not provide for the further production of ammonia from ammonium sulfates. Nitrogen blowing and vacuuming are rather energy-consuming methods of ammonia extraction, which requires additional research on economic attractiveness. In addition, they did not provide for the receipt of ammonia in the form of usable energy. Gas recirculation is also energy-consuming, and ammonia sorption with sulfate acid also did not provide for the production of ammonia in a form suitable for use as an energy carrier. The addition of minerals led to the sorption of ammonia with these minerals, the extraction of ammonia from which was not supposed. Thus, other approaches to obtaining ammonia during anaerobic fermentation did not provide for the production of ammonia in forms suitable for use as carbon-free fuels. All these methods are effective in controlling the nitrogen content in the bioreactor when decomposing livestock waste; however, they did not make it possible to ensure the production of ammonia in the form suitable for its use as fuel.

All this suggests that it is advisable to conduct a study on the extraction of ammonia from livestock waste for carbonfree energy generation.

\section{The aim and objectives of the study}

The purpose of this study was to propose a method of ammonia production, which is environmentally friendly, energy-efficient, and does not involve the use of fossil fuels, which could potentially contribute to the development of carbon-free energy generation. This would make it possible to obtain ammonia in a cheap and carbon-free way, which could ensure the development of ammonia-based energy generation.

To accomplish the aim, the following tasks have been set:

- to consider a method for controlling the concentration of ammonium nitrogen ( $\mathrm{AN}$ ) in the biogas reactor, which is planned to be taken as a basis;

- to adapt the method of controlling the concentration of ammonium nitrogen to produce ammonia;

- to evaluate the energy efficiency of the proposed method of ammonia production;

- to evaluate the potential of ammonia production by the new method;

- to analyze the techniques of using ammonia produced.

\section{The study materials and methods}

The kinetics of the release of ammonia from the solution of diammonium phosphate (DAP), when heated to different temperatures, were investigated using the installation shown in Fig. 1.

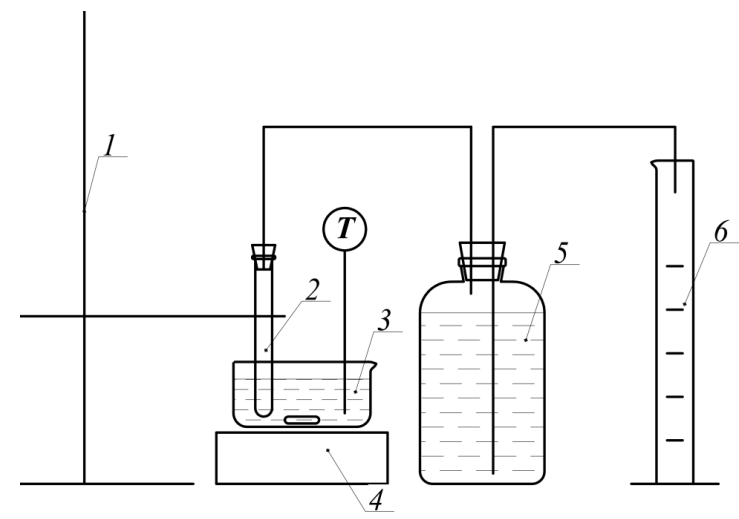

Fig. 1. Installation to study the ammonia release kinetics when heating a solution of diammonium phosphate: 1 - laboratory tripod; 2 - test tube with a solution of diammonium phosphate; 3 - crystallizer with water; 4 - magnetic heated stirrer; 5 - bottle with a saturated solution of sodium chloride; 6 - measuring cylinder

Test tube 2 with a DAP solution was immersed in a crystallizer with heated water 3 and fixed in a laboratory tripod 1 . 
Crystallizer 3 was placed on magnetic stirrer 4 . It provided water heating and the same temperature value throughout its layer. The temperature of the water in the crystallizer was controlled with a digital thermometer. The ammonia, released during heating, entered bottle 5 filled with a saturated solution of sodium chloride. In this case, the liquid under pressure created by the gas entered measuring cylinder 6 . The salt solution was used to prevent the dissolution of ammonia in water. The amount of sodium chloride solution in measuring cylinder 6 was used to estimate the volume of ammonia released as a result of heating. The amount of energy required to obtain ammonia by heating DAP was determined at the installation shown in Fig. 2.

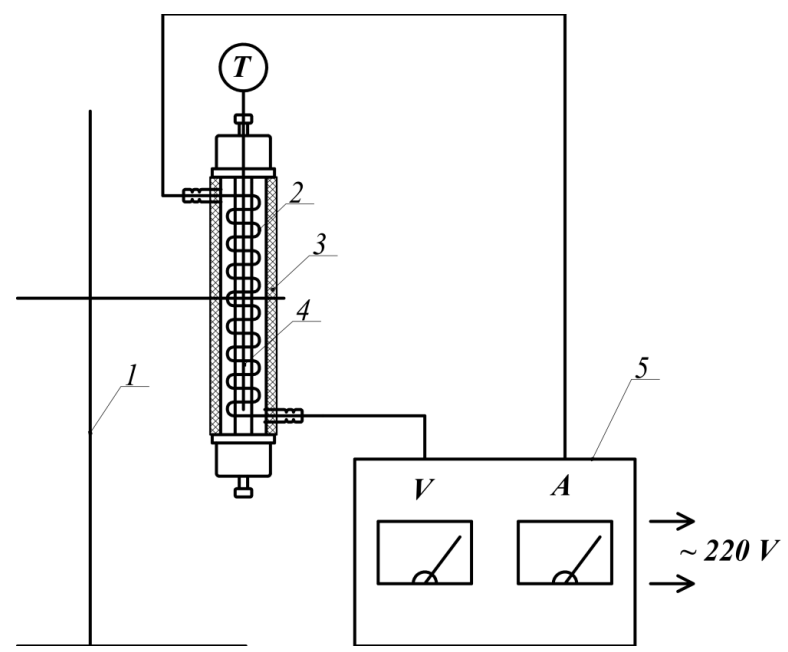

Fig. 2. Installation to estimate the amount of energy needed to produce ammonia: 1 - laboratory tripod; 2 - heating wire; 3 - thermal insulation; 4 - glass tube with diammonium phosphate solution; 5 - laboratory power supply

The glass tube, in the middle of which there was another glass tube 4 with DAP solution, was fixed in laboratory tripod 1. Heating wire 2 was wound around inner tube 4. The outer tube was coated with thermal insulation 3 . The solution was heated with heating wire 2, the voltage of which was supplied from laboratory power supply unit 5 . The voltage and current were measured using a voltmeter and an ammeter built into power supply unit 5 . We controlled the temperature of the solution in glass tube 4 with a digital thermometer. Taking into consideration the voltage, electric current, and heating time, the amount of energy spent on ammonia production was determined.

\section{Results of devising an ammonia production method}

5. 1. Method to control ammonium nitrogen concentration in a biogas reactor

The proposed ammonia production technology is based on the previously developed method for controlling the concentration of ammonium nitrogen (AN) directly in the biogas reactor $(\mathrm{BR})[23]$.

The essence of the developed method is to remove AN from the liquid phase by sorption of ammonia from the gas phase by non-volatile sorbent, which is directly in the apparatus but does not come into contact with the substrate [23].

It was proposed to use as sorbent a solution of phosphoric acid (PA) since it can react with ammonia, is non-volatile, and, as a result of the reaction, a product is formed useful for agriculture (ammonium phosphates) [24].

Depending on the amount of ammonia interacting with $\mathrm{PA}$, different reaction products are formed: $\mathrm{NH}_{4} \mathrm{H}_{2} \mathrm{PO}_{4}$, $\left(\mathrm{NH}_{4}\right)_{2} \mathrm{HPO}_{4}$, and $\left(\mathrm{NH}_{4}\right)_{3} \mathrm{PO}_{4}$. Monoammonium phosphate (MAP) and DAP have practical significance [25]. Ammonium orthophosphate $\left(\mathrm{NH}_{4}\right)_{3} \mathrm{PO}_{4}$ has no practical application. Given this, the replacement of the sorbent is carried out with the formation of MAP (Fig. 3) or DAP (Fig. 4).

When neutralizing PA to MAP, the depth of removal of AN from the liquid phase of BR is higher than when neutralizing to diammonium phosphate since the reaction rate is higher. When neutralizing $\mathrm{PA}$ to $\mathrm{NH}_{4} \mathrm{H}_{2} \mathrm{PO}_{4}$, the solution is drained at $\mathrm{pH} 4.5$; and to $\left(\mathrm{NH}_{4}\right)_{2} \mathrm{HPO}_{4}-$ at $\mathrm{pH}$ 8.0.

Ammonium phosphates can be obtained in solid form. After extraction from the reactor, the resulting solution is cooled to ambient temperature and becomes oversaturated. Due to the introduction of primer, crystallization centers are formed, and part of ammonium phosphates are released, which cannot be dissolved at this temperature (Table 1) [26, 29].

The effectiveness of isolating MAP from the solution when cooled in the form of crystals is much higher than DAP (Fig. 5).

$\mathrm{NH}_{4} \mathrm{H}_{2} \mathrm{PO}_{4}$ is dried at a temperature from $100{ }^{\circ} \mathrm{C}$ to $110{ }^{\circ} \mathrm{C} ;\left(\mathrm{NH}_{4}\right)_{2} \mathrm{H}_{2} \mathrm{PO}_{4}$ - at a temperature from $60{ }^{\circ} \mathrm{C}$ to $70^{\circ} \mathrm{C}$. The isolated liquid can be returned to the reactor after adding acid solution (Fig. 3, 4) [26].

The effectiveness of the proposed AN concentration control method was shown in ammonium salt solutions that simulate a substrate with a high concentration of the inhibitor (Fig. 6) [26].

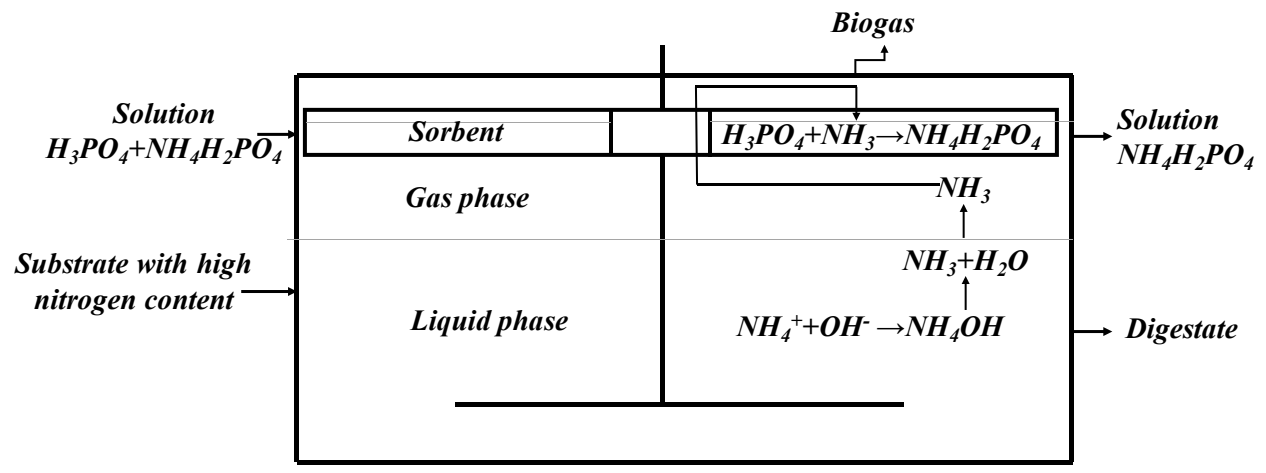

Fig. 3. Adjustment of ammonium nitrogen concentration in a biogas reactor by sorption of ammonia from the gas phase and obtaining a solution of monoammonium phosphate 


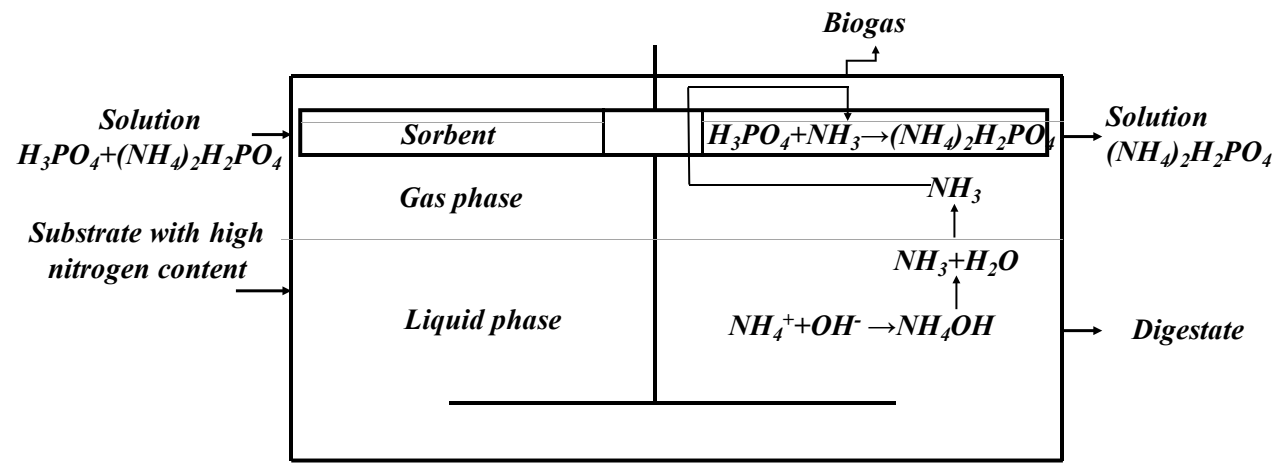

Fig. 4. Adjustment of ammonium nitrogen concentration in a biogas reactor by sorption of ammonia from the gas phase and production of diammonium phosphate solution

Table 1 by sodium hydroxide to the required $\mathrm{pH}$ value, was placed in

Ammonium phosphates solubility at different temperatures, $\mathrm{g} / 100 \mathrm{~g} \mathrm{H}_{2} \mathrm{O}$

\begin{tabular}{|c|c|c|c|c|c|c|}
\hline \multirow{2}{*}{$\begin{array}{c}\text { Sub- } \\
\text { stance }\end{array}$} & \multicolumn{6}{|c|}{ Temperature, ${ }^{\circ} \mathrm{C}$} \\
\cline { 2 - 7 } & 0 & 10 & 20 & 30 & 40 & 50 \\
\hline MAP & 22.7 & 29.5 & 37.4 & 46.4 & 56.7 & 69.0 \\
\hline DAP & 42.9 & 62.9 & 68.9 & 75.1 & 81.8 & 89.2 \\
\hline
\end{tabular}

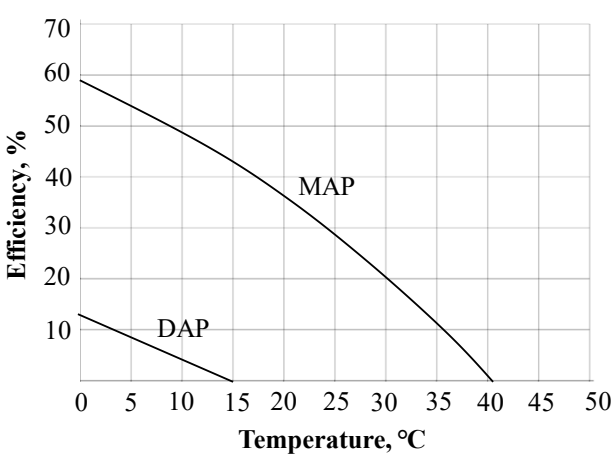

Fig. 5. Theoretical effectiveness of ammonium phosphates removal from solution when cooled to a certain temperature

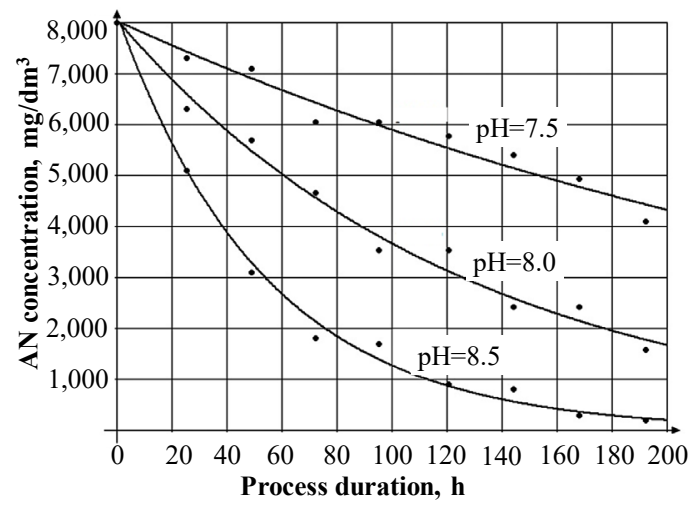

Fig. 6. Decrease in the concentration of ammonium nitrogen in a solution of $0.25 \mathrm{dm}^{3}$ as a result of ammonia sorption from the gas phase with phosphoric acid with a concentration of $4 \mathrm{~mol} / \mathrm{dm}^{3}$ at different $\mathrm{pH}$ values of the medium and a temperature of $50{ }^{\circ} \mathrm{C}$

The experiment was conducted as follows. A bottle containing $0.25 \mathrm{dm}^{3}$ of ammonium chloride solution, alkalized a dry-air thermostat. The measuring cup containing $0.05 \mathrm{dm}^{3}$ of PA solution was placed on the bottom of the bottle. The contact area of the ammonium chloride solution and gas phase was $71.0 \mathrm{~cm}^{2}$. The contact area of the PA solution surface and the gas phase was $15.3 \mathrm{~cm}^{2}$. Taking into consideration the data in Fig. 6, sorption proceeds well across the entire range of $\mathrm{pH}$ values and was most intense at $\mathrm{pH}=8.5$. In addition, the effectiveness of the proposed method to control the concentration of AN was shown directly at the AD of chicken manure under a semi-continuous mode (Fig. 7) [26].

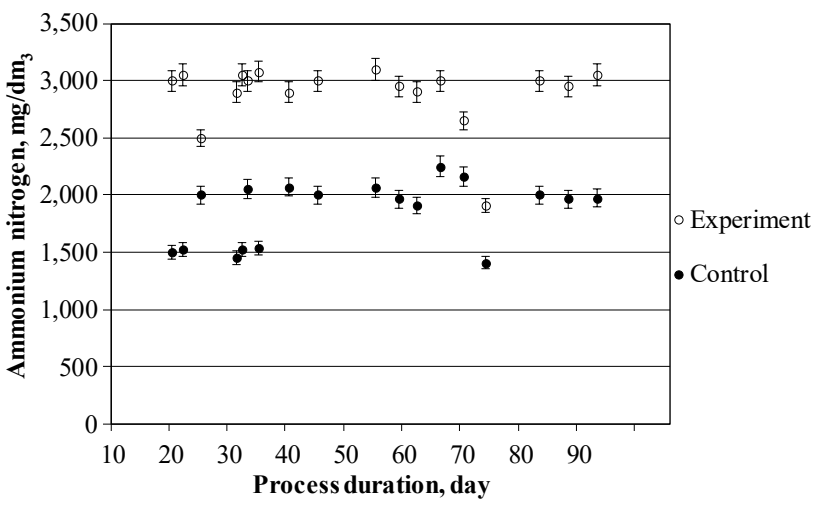

Fig. 7. Concentration of ammonium nitrogen in the experimental and control reactors during the experiment

The AD of chicken manure was carried out under thermophilic conditions at a temperature of $50{ }^{\circ} \mathrm{C}$. The HRT in $\mathrm{BR}$ was 10 days; the moisture content of the substrate was $90 \%$. The useful volume of the biogas reactors was $2 \mathrm{dm}^{3}$. The content of the device was stirred with a mechanical stirrer at a rotation speed of $38.4 \mathrm{rpm}$ for 15 minutes each hour. PA concentration was $4 \mathrm{~mol} / \mathrm{dm}^{3}$. The contact area of the sorbent surface with the gas phase was $0.025 \mathrm{~m}^{2}$; that of the surface of the substrate with the gas phase was $0.035 \mathrm{~m}^{2}[26]$.

The application of this method ensured a decrease in the concentration of AN by $33.7 \%$, and free ammonia by $41.0 \%$. At the same time, the concentration of methane in the biogas produced in the prototype was $5 \%$ higher than that in the control in absolute terms, and by $8.3 \%$ in relative terms [26]. In addition, the results of mathematical modeling showed that the proposed method is effective enough to regulate the concentration of AN under the conditions of liquid phase recirculation (Fig. 8) [27]. 


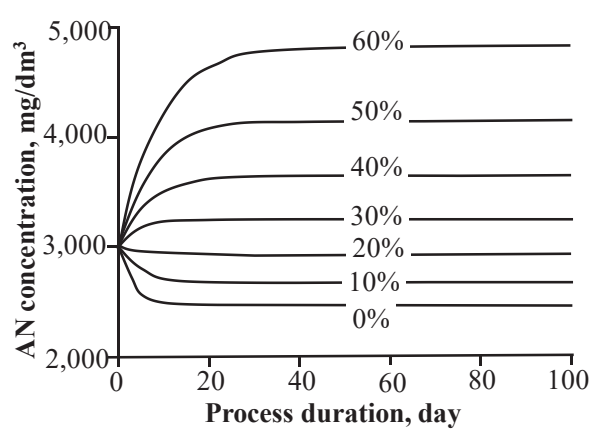

$a$

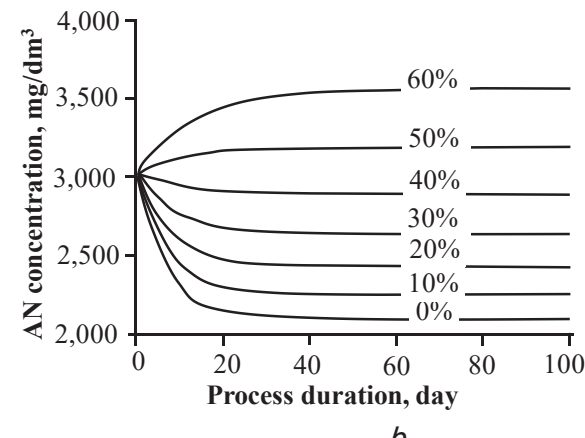

$b$

Fig. 8. Concentration of ammonium nitrogen in the biogas reactor in which ammonia sorption occurs from the gas phase at the $\mathrm{pH}$ of the liquid phase 8.0, after the start of recirculation at its various degrees: $a-$ at the hydraulic retention time of 5 days; $b-$ at the hydraulic retention time of 10 days

It was accepted that the process is carried out under a thermophilic mode at a temperature of $50{ }^{\circ} \mathrm{C}$, the moisture content of the substrate $-90 \%$, and HRT -5 and 10 days. The concentration of PA is $4 \mathrm{~mol} / \mathrm{dm}^{3}$. The ratio of sorbent area and the substrate is 1:4.6; the diameter of the apparatus to the depth of the substrate is $1: 1.5$. The concentration of AN in BR without removal is taken equal to $3,000 \mathrm{mg} / \mathrm{dm}^{3}$. The maximum degree of recirculation of the effluent is $60 \%$, shown on the plots, corresponds to the complete replacement of water used for breeding chicken manure from the native moisture content of $75 \%$ to $90 \%$ [27]. The degree of removal can be significantly increased by changing the geometric dimensions of BR, increasing the area of contact of sorbent with the gas phase, and the hydraulic retention time (HRT) [27].

5. 2. Adapting the method of controlling the concentration of ammonium nitrogen to produce ammonia

The method of controlling the concentration of AN in BR in the case of sorbent regeneration can be considered as an ammonia production technology.

Regeneration is possible when the resulting sorption product is $\left(\mathrm{NH}_{4}\right)_{2} \mathrm{HPO}_{4}$. When heating the latter to a temperature above $70^{\circ} \mathrm{C}$, ammonia is released:

$$
\left(\mathrm{NH}_{4}\right)_{2} \mathrm{HPO}_{4} \rightarrow \mathrm{NH}_{4} \mathrm{H}_{2} \mathrm{PO}_{4}+\mathrm{NH}_{3} \uparrow \text {. }
$$

In this case, the sorbent in $\mathrm{BR}$ is $\mathrm{NH}_{4} \mathrm{H}_{2} \mathrm{PO}_{4}$ (Fig. 9).

Our experiment considered the possibility of obtaining ammonia by heating the solution and $\left(\mathrm{NH}_{4}\right)_{2} \mathrm{HPO}_{4}$ crystals. It was found that a DAP solution should be heated since during the heating of DAP crystals there was no significant release of ammonia.
An experiment was conducted on the effect of temperature on the process of regeneration of sorbent solution. The decomposition of $\left(\mathrm{NH}_{4}\right)_{2} \mathrm{HPO}_{4}$ with removal was carried out at temperatures of $70,80,85,90,95$, and $100^{\circ} \mathrm{C}$. The regeneration rate was maximum at the beginning of the process and decreased over time. Higher temperatures caused a higher rate of ammonia release (Fig. 10).

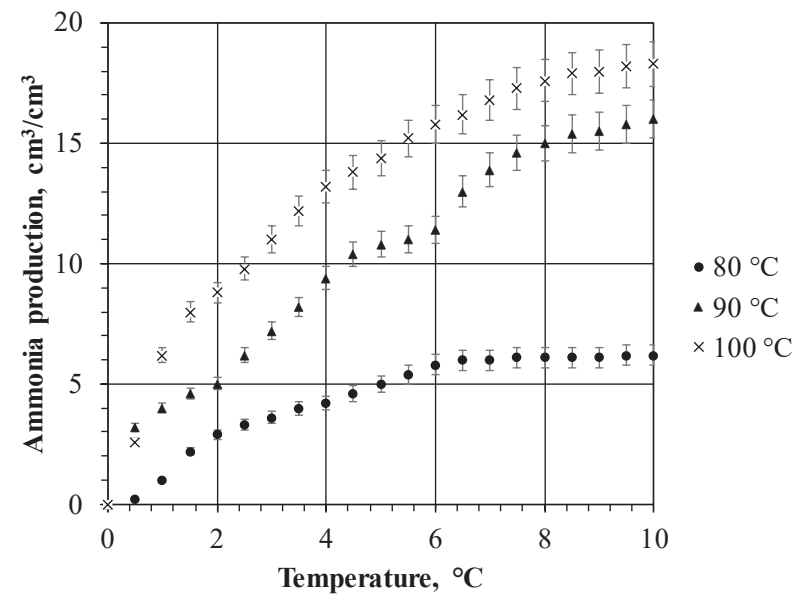

Fig. 10. Kinetics of ammonia release from diammonium phosphate solution at different temperatures

That means that the higher the $\left(\mathrm{NH}_{4}\right)_{2} \mathrm{HPO}_{4}$ concentration in solution, the less energy is required to produce a unit mass of ammonia. The total amount of ammonia isolated during 10 minutes of sorbent regeneration varies depending on the temperature (Fig. 11).

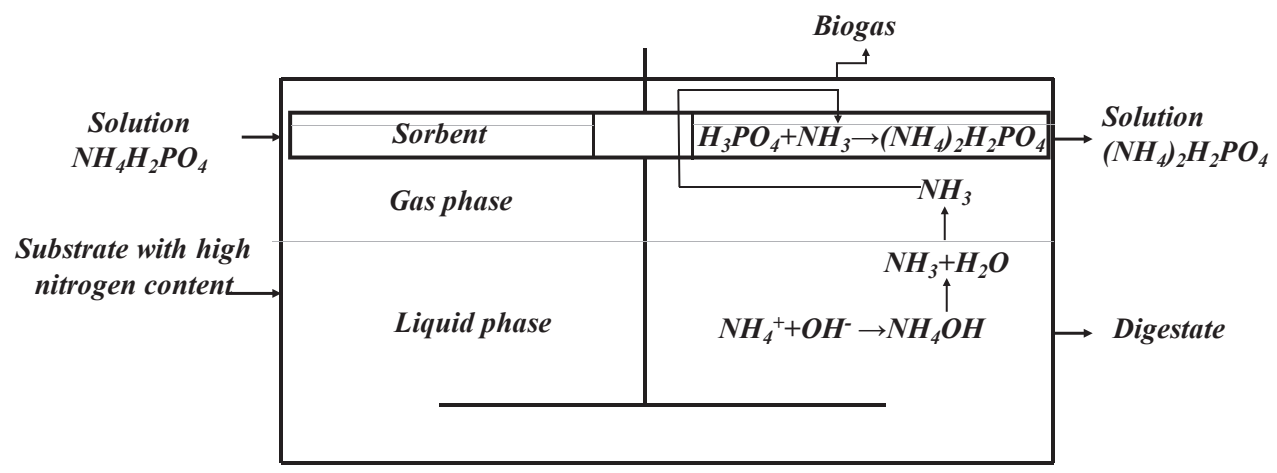

Fig. 9. Adjustment of ammonium nitrogen concentration in a biogas reactor by sorption of ammonia from the gas phase with a monoammonium phosphate solution 


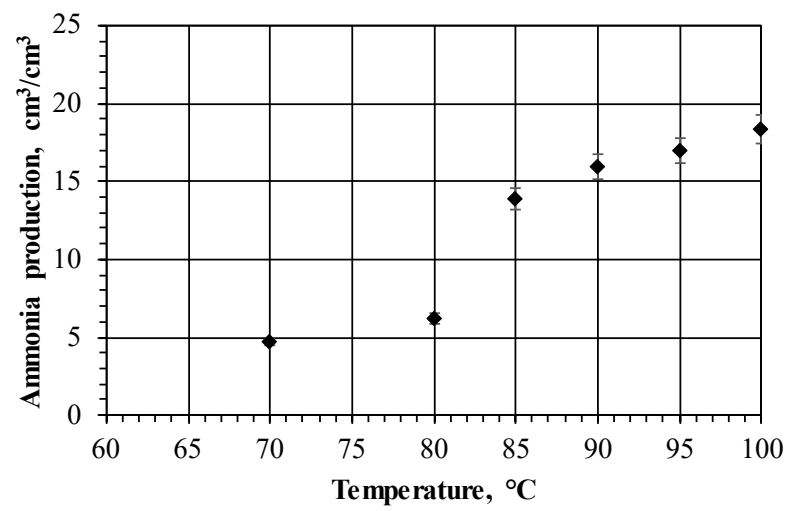

Fig. 11. Total ammonia removal from diammonium phosphate solution at different temperatures

Rising temperatures caused a greater ammonia yield. Thus, with increasing temperature, it is possible to increase the yield of ammonia as a product, which, with the use of energy-saving technologies, can be an important factor in justifying technologies.

\section{3. The energy efficiency of the proposed ammonia} production method

The amount of energy needed to obtain a ton of ammonia by the Haber-Bosh method is 38 GJ. At the same time, 22.5 GJ energy can be obtained from one ton of ammonia. Thus, the amount of energy obtained from one ton of ammonia is much lower than the one that was spent for its production.

During the regeneration of sorbent solution in the laboratory, before gas production stopped, energy consumption was $111 \mathrm{GJ} / \mathrm{t}$.

It is important to note that thermal energy produced by the cogeneration plant can be used to regenerate sorbent. For example, at a biogas plant that processes manure from 750 thousand chickens and with the values of the technological regime parameters used in the experiment, this is quite feasible even with the consumption of energy of $111 \mathrm{GJ}$ per ton of ammonia. Under such conditions, one can get $364.2 \mathrm{~kg}$ of ammonia per day, which requires 40.4 GJ of energy. At the same time, the amount of heat generated with the help of a cogeneration unit is $64.1 \mathrm{GJ}$. One can also use the heat of the fermented substrate, which is released from the biogas plant.

\section{4. The potential of ammonia production by the} new method

The proposed method of ammonia production can be used in the processing of many types of waste with high nitrogen content. These wastes include chicken manure, pig manure, cattle manure, sheep manure, horse manure, slaughter waste, excess aerobic active silt, etc.

For example, at a poultry farm with a population of 750 thousand laying hens under the conditions created in the experiment [26], one can get 132 tons of ammonia per year.

The assessment of the potential of ammonia production at the scale of the EU and the USA was carried out; a detailed analysis was performed using an example of a country with a developed agricultural sector. The total number of livestock of animals is higher in the EU than in the USA. However, the structure of animal husbandry is slightly different. Thus, the EU has a much larger number of chicken heads, and in the USA much more heads of pigs. Fig. 12 shows the number of livestock in the U.S. $(a)$ and EU $(b)$ in the main livestock sectors.
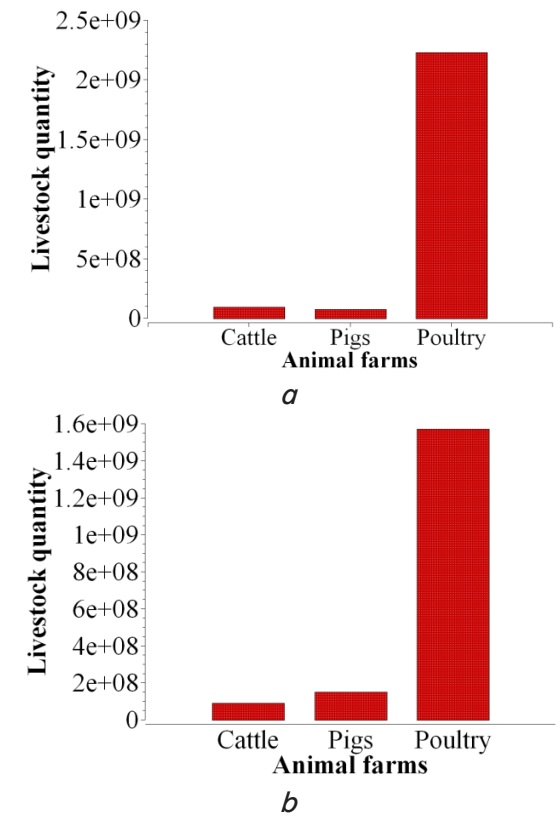

Fig. 12. Quantity of livestock in the sectors of animal husbandry: $a-$ in the USA; $b-$ in Europe

Below we consider the potential to produce ammonia from livestock waste in the EU and the USA. To this end, using the data given in Table 2, the maximum amount of ammonia that can be obtained from one animal per day was calculated (Fig. 13).

Table 2

Livestock waste parameters needed to assess the potential of ammonia production

\begin{tabular}{|c|c|c|c|}
\hline Waste & $\begin{array}{c}\text { Total nitro- } \\
\text { gen, \% dry } \\
\text { matter [28] }\end{array}$ & $\begin{array}{c}\text { Moisture } \\
\text { con- } \\
\text { tent, \% [29] }\end{array}$ & $\begin{array}{c}\text { Waste mass from } \\
\text { one animal, } \\
\text { kg/day [29] }\end{array}$ \\
\hline Chicken manure & 4.6 & 75 & 0.16 \\
\hline Pig manure & 3.9 & 86 & 5.1 \\
\hline Cattle manure & 2.6 & 86 & 55 \\
\hline Cow manure & 2.9 & 86 & 55 \\
\hline
\end{tabular}

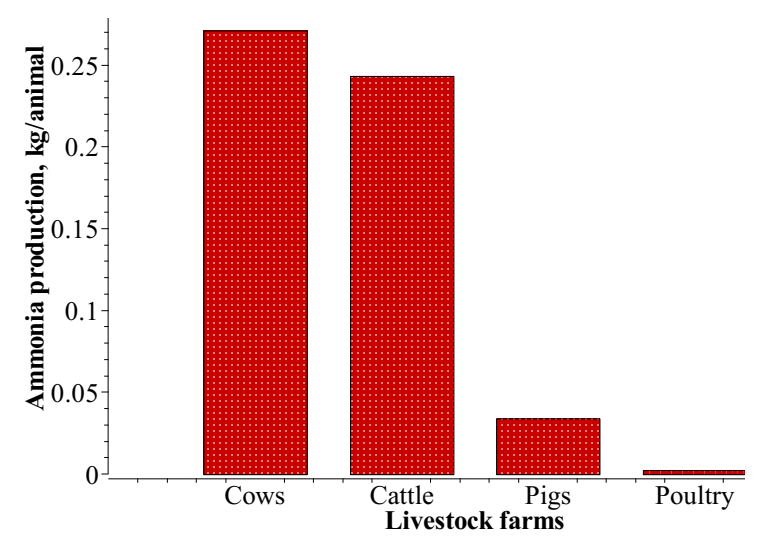

Fig. 13. The potential for the production of ammonia from the waste of one animal per day

The largest amount of ammonia can be obtained from poultry waste both in the EU and in the USA. In the EU countries, in comparison with the United States, pig waste has a greater potential for ammonia production, and cattle waste in the Unit- 
ed States compared to EU countries. The potential of ammonia production in the United States and European countries in the sectors of animal husbandry is shown in Fig. 14.
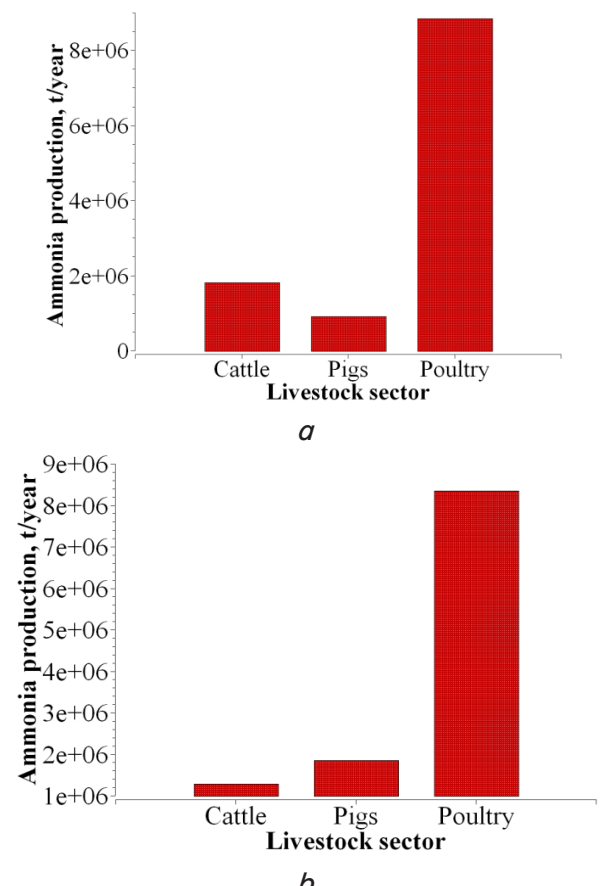

Fig. 14. The potential of ammonia production in countries by livestock sector: $a-$ in the USA; $b-$ in Europe

When assessing the potential of ammonia production, industrial livestock was taken into consideration; animals that are in households of the population were not taken into consideration. This is due to the need to be able to centrally collect livestock waste in large quantities using the means of mechanization and automation of the process. Poultry and cattle have the greatest potential for ammonia production 88,844 and 88,468 tons, respectively.

In terms of energy content, liquid ammonia contains $15.6 \mathrm{MJ} / \mathrm{dm}^{3}$. This is $70 \%$ more than liquid hydrogen $\left(9.1 \mathrm{MJ} / \mathrm{dm}^{3}\right.$ at cryogenic temperatures) or almost three times more than compressed hydrogen $\left(5.6 \mathrm{MJ} / \mathrm{dm}^{3}\right.$ at $\left.70 \mathrm{MPa}\right)$ [30]. This may indicate that ammonia is promising in terms of its energy use as a fuel compared to hydrogen. Ammonia is much cheaper to store for a long time compared to hydrogen, as well as to transport [31]. The infrastructure for the processing and transportation of ammonia already exists [15,31], the supply chain and the rules for handling are already in place [32]. Given this, it is possible to argue that if there is a cheap method of ammonia production, it will be possible to use the existing infrastructure for the implementation of ammonia-powered energy technologies.

Ammonia has many applications in carbon-free energy. In August 2014, a team led by Kobayashi and Iki was the first in the world to use an ammonia turbine to drive the generator. Their turbine was optimized for the use of ammonia with the help of additional turbine blades, which create a high-temperature mixture of fuel under high pressure. The team uses the system with a maximum output power of 50 $\mathrm{kW}$. Initially, they managed to achieve a stable output power of $21 \mathrm{~kW}$ using a mixture that contained $30 \%$ ammonia and $70 \%$ kerosene. By September 2015, they had reached a capacity of $41.8 \mathrm{~kW}$ per mixture of methane and ammonia. Subsequently, they managed to achieve the same output power with $100 \%$ ammonia [33]. At the same time, given the constant optimization processes, it is possible to achieve more power. Given this, it is possible to assert that ammonia, both in the mixture and in its pure form, can be used for the operation of turbines. In 2018, industrial tests were carried out on a two-fuel turbine with a capacity of $2 \mathrm{MW}$ produced by IHI Corporation, which worked on ammonia and natural gas. It was found that the operation of the gas turbine engine is stable in the entire range of ammonia mixing ratios from zero to $20 \%$. The combustion efficiency exceeds $99.8 \%$ for all test conditions [34]. Thus, one of the potential methods of applying ammonia as a green fuel is to use it to operate turbines.

In 2017, The Japanese Chugoku Electric Power Corporation successfully demonstrated the joint combustion of coal with $1 \%$ ammonia (in terms of total energy content) at one of the commercial coal-fired power plants $(120 \mathrm{MW})$. The use of ammonia as fuel raises concerns about an increase in NOx emissions but, during the demonstration, it was possible to keep them within the normal range and avoid ammonia from entering the exhaust gases [35]. Thus, the use of ammonia in combination with coal at power plants is possible, and emissions resulting from the operation of such power plants do not exceed the standards for the content of nitrogen oxides. The Japanese manufacturer IHI Corporation announced on March 28, 2018, that it had successfully demonstrated the joint combustion of ammonia and coal in a $20 \%$ ammonia fuel mixture. It is noted that the company's technology could be adapted to existing coal boilers [25]. Consequently, the joint combustion of ammonia and coal also has the potential to be applied. In addition, given that it is possible to use existing coal-based boilers, that can ensure a significant propagation of such technology.

Ammonia can be used in internal combustion engines. Based on previous studies, in order for ammonia to become a viable fuel for internal combustion engines, it must be mixed with other fuels as combustion accelerators. To this end, they usually chose a two-fuel approach [36]. It has been demonstrated that internal combustion engines can work successfully on ammonia/gasoline mixture [37-39] and ammonia/diesel fuel [40]. Thus, as a rule, for the operation of internal combustion engines running on ammonia, a two-fuel approach is used. Engines powered by ammonia are characterized by lack of corrosion, low power losses, and low lubricant consumption [41-43]. Given that road transport creates a significant environmental burden, the use of ammonia could reduce this load and change the environmental footprint of road transport.

In July 2015, the Kyoto University research team successfully demonstrated its solid oxide fuel cell, which operated directly on ammonia, with a capacity of $200 \mathrm{~W}$, which, at the time, was "the largest in the world" [44]. The Japanese production concern IHI announced on May 16, 2018, that it "successfully generated a class capacity of $1 \mathrm{~kW}$ " using a solid oxide fuel cell that worked directly on ammonia [45].

The U.S. Department of Energy's Advanced Research Projects Agency has demonstrated that ammonia is already the cheapest and most proven technology for long-term large-scale energy storage for more than one day [46]. Ammonia can be used in heavily decarbonized industries such as metallurgy and marine transport [47-49]. Given the above, ammonia has a high potential for use while exploiting existing infrastructure. 


\section{Discussion of results of devising the ammonia production method for carbon-free energy generation}

The application of the proposed method has a double effect - a decrease in AN in bioreactors, which leads to a decrease in their inhibition, and the production of ammonia itself. The need to regulate the concentration of AN during AD is based on its ability to inhibit the process [17, 18, 50,51]. Both AN and sulfides [52] can inhibit the process but, for the processing of manure, AN is more harmful. The toxic effect of AN is associated with undissociated ammonia. It has been shown that it diffuses through cell membranes and is ionized with the formation of ammonium ions $\mathrm{NH}_{4}^{+}$, which leads to a $\mathrm{pH}$ imbalance in the middle and outside of the bacterial cell. That negatively affects both the transport of substances and the activity of enzymes [53]. The factors controlling process inhibition are the solids content in the substrate, HRT, $\mathrm{pH}$, temperature, and the presence of ions that are inhibitor antagonists [54]. Inhibition of the AD process by a high concentration of AN can lead to significant economic losses during BR operation. As indicated above, it is proposed to use PA as a sorbent. Under a thermophilic mode, it is advisable to use PA with a concentration of $4 \mathrm{~mol} / \mathrm{dm}^{3}$ since, at this concentration, there is neither a significant decrease in volume due to moisture evaporation nor its increase due to the hygroscopicity of acid [24]. Fig. 8 demonstrates that the method is effective at reducing the content of $\mathrm{AN}$ in the $\mathrm{AD}$ process.

The industry produces extraction PA and thermal PA. Extraction PA is obtained by decomposition of natural phosphates with sulfuric acid and separation of the formed solid phase (calcium sulfate) from the PA solution [55]. Thermal PA is produced by electrical distillation of phosphorus and its oxidizing followed by hydration of the resulting phosphorus anhydride to PA [55]. As a sorbent in the BR, one can use thermal PA or purified extraction PA.

In the case of untreated extraction PA, impurities react with ammonia, as a result of which iron, aluminum, gypsum, etc. enter the sediment [56]. In order to avoid the accumulation of salts at the bottom of the tank with acid located inside the $\mathrm{BR}$, it is not recommended to use untreated PA.

During the regeneration of sorbent solution in the laboratory, before the cessation of gas production, energy consumption was $111 \mathrm{GJ} / \mathrm{t}$. This value is rather given not to compare the proposed method with the Gaber-Bosch process but to show that this amount of energy is already sufficient for the production of ammonia.

Of course, it is possible to reduce the energy costs of the method, since, during the regeneration of sorbent, the task was not to reduce them due to any special design solutions or the selection of technological parameters but to determine its possibility.

Based on the peculiarities of measuring the volume of ammonia generated by DAP heating, the amount of gas generated is somewhat underestimated. In particular, the density of the salt solution moved from one container to another, the levels of liquid in the container into which ammonia fell, and the height of the salt solution transfusion into the measuring cylinder were not taken into consideration. Consequently, the amount of energy needed to obtain a unit mass of ammonia observed during the study is overstated.

The process of sorbent regeneration with the formation of ammonia should be optimized. To this end, it is necessary to take into consideration the temperature and heating time since the amount of energy spent on obtaining a unit of ammonia mass depends on those parameters.

It is necessary to consider heating the sorbent solution inside the $\mathrm{BR}$ above the $\mathrm{AD}$ temperature. Thus, it is theoretically possible to increase the concentration of sorbent without moisture entering it. That can lead not only to an increase in the sorption rate of ammonia from the gas phase and, accordingly, to an increase in the depth of removal from the liquid phase but also to an increase in the concentration of the resulting DAP, which could reduce energy consumption for ammonia production.

When assessing the potential of ammonia production, it was assumed to use all the nitrogen contained in the litter of animals, which is impossible. Thus, the obtained values characterize the possible limits of ammonia production.

At the same time, it is important to note that the proposed method of ammonia production can only be used for organic, not mineral waste. In addition, such wastes should be suitable for $\mathrm{AD}$ and have a high nitrogen content. As a result of research, it was found that without optimization in laboratory conditions, $111 \mathrm{GJ} / \mathrm{t}$ of ammonia is required, which requires additional further research in order to reduce this indicator.

Determining the potential of ammonia production allows us to draw conclusions about the prospects of using this method under industrial conditions. Thus, the annual potential of ammonia production in the main livestock sectors in Ukraine is 263,610 tons. This is comparable to the traditional production of ammonia in the country in 2019 (183,000 tons). A similar situation applies to European countries and the United States.

Our analysis of Fig. 14, 15 reveals that the largest amount of ammonia in the analyzed countries can be obtained from poultry farming. Probably, such a trend is relevant for the world. Thus, the results from the anaerobic fermentation of chicken manure using the ammonia extraction method [26,27], which were carried out earlier, can be directly used to implement such technology.

A separate important issue is the use of ammonia since it is a new and quite promising type of fuel, provided it is produced carbon-free. However, its use requires additional research, and its industrial use is only beginning to gain relevance. As noted above, ammonia has a series of practical applications and developed infrastructure. In addition, in the context of recent events, in particular regarding the gas supply infrastructure, part of such infrastructure will be left without use or used to a lesser extent. Such infrastructure could also be adapted for transporting ammonia obtained carbon-free biologically.

Further work will tackle the optimizing of technological parameters to increase the economic efficiency of the proposed carbon-free method of ammonia production.

\section{Conclusions}

1. When devising a method to produce ammonia, the method of control of AN concentration in BR was taken as a basis. It involves removal from the liquid phase by sorption of ammonia from the gas phase. The sorbent is a non-volatile substance that is directly in the apparatus but does not come into contact with the substrate.

2. The proposed method of ammonia production is based on ammonia sorption from the gas phase of the reactor with MAP solution. The resulting DAP solution is drained from the $\mathrm{BR}$ upon reaching a $\mathrm{pH}$ of 8.0 and heated above $70^{\circ} \mathrm{C}$, accompanied by the removal of ammonia. 
3. During the regeneration of sorbent solution until the cessation of gas production, energy consumption was $111 \mathrm{GJ} / \mathrm{t}$ of ammonia. For the purpose of regeneration, the thermal energy of the cogeneration unit can be used.

4. The use of this method to produce ammonia on an industrial scale is feasible. In Europe and the USA, the production potential of ammonia is up to $11,482,651.15$ and $11,582,169.5$ tons per year, respectively. The potential of ammonia production in the main livestock sectors in Ukraine is up to 263,610 tons per year, which is comparable to the production of ammonia in the country in the traditional way. Ammonia as a fuel can be used as a single component of fuel, as well as in two-fuel systems. Ammonia can be used in turbines, for direct combustion, in particular in boilers, for the operation of internal combustion engines, in solid oxide fuel cells, and in other devices and technologies. Engines running on ammonia are characterized by lack of corrosion, low power losses, and low lubricant consumption.

\section{References}

1. 2030 climate \& energy framework. European Commission. Available at: https://ec.europa.eu/clima/policies/strategies/2030_en

2. Reflection Paper - Towards a Sustainable Europe By 2030 (2019). European Commission. Available at: https://ec.europa.eu/info/ sites/default/files/rp_sustainable_europe_30-01_en_web.pdf

3. Going Climate-Neutral by 2050. European Commission. Available at: https://op.europa.eu/en/publication-detail/-/publication/92f6d5bc-76bc-11e9-9f05-01aa75ed71a1

4. Brouwer, K. M. (2021). Road to EU Climate Neutrality by 2050. Brussels. Available at: https://roadtoclimateneutrality.eu/ Energy_Study_Full.pdf

5. Submission of Japan's Intended Nationally Determined Contribution (2015). Ministry of Economy, Trade and Industry. Available at: https://www4.unfcc.int/sites/ndcstaging/PublishedDocuments/Japan\%20First/20150717_Japan\%27s\%20INDC.pdf

6. Kobayashi, H., Hayakawa, A., Somarathne, K. D. K. A., Okafor, E. C. (2019). Science and technology of ammonia combustion. Proceedings of the Combustion Institute, 37 (1), 109-133. doi: https://doi.org/10.1016/j.proci.2018.09.029

7. Energiekonzept für eine umweltschonende, zuverlässige und bezahlbare Energieversorgung (2010). München. Available at: https://www.bmwi.de/Redaktion/DE/Downloads/E/energiekonzept-2010.pdf?_blob=publicationFile\&v=5

8. Climate Change Act 2008. Available at: https://www.legislation.gov.uk/ukpga/2008/27/contents

9. Strategiya. Dolgosrochnogo razvitiya rossiyskoy federacii s nizkim urovnem vybrosov parnikovyh gazov do 2050 goda. Available at: https://economy.gov.ru/material/file/babacbb75d32d90e28d3298582d13a75/proekt_strategii.pdf

10. Hot Cities: battle-ground for Climate change. Available at: https://mirror.unhabitat.org/downloads/docs/E_Hot_Cities.pdf

11. Apple commits to be 100 percent carbon neutral for its supply chain and products by 2030 (2020). Apple. Available at: https://www. apple.com/newsroom/2020/07/apple-commits-to-be-100-percent-carbon-neutral-for-its-supply-chain-and-products-by-2030/

12. Salmon, N., Bañares-Alcántara, R. (2021). Green ammonia as a spatial energy vector: a review. Sustainable Energy \& Fuels, 5 (11), 2814-2839. doi: https://doi.org/10.1039/d1se00345c

13. Researchers aim to make ammonia production $100 \%$ green. Available at: https://www.eurekalert.org/news-releases/538445

14. Sosna, M. Kh., Kasym, O. N. (2017). The main trends in the technology development of ammonia production. Oil \& Gas Chemistry, 4, 17-21. doi: https://doi.org/10.24411/2310-8266-2017-00036

15. Service, R. F. (2018). Ammonia - a renewable fuel made from sun, air, and water - could power the globe without carbon. Science. Available at: https://www.science.org/content/article/ammonia-renewable-fuel-made-sun-air-and-water-could-power-globe-without-carbon

16. Abouelenien, F., Elsaidy, N., Nakashimada, Y. (2013). Simultaneous Ammonia removal and Methane Production from Chicken Manure under Dry Thermophilic Condition. Journal of American Science, 9 (10), 90-94. Available at: http://www.jofamericanscience. org/journals/am-sci/am0910/011_20294am0910_90_94.pdf

17. Wang, X., Gabauer, W., Li, Z., Ortner, M., Fuchs, W. (2018). Improving exploitation of chicken manure via two-stage anaerobic digestion with an intermediate membrane contactor to extract ammonia. Bioresource Technology, 268, 811-814. doi: https://doi.org/ 10.1016/j.biortech.2018.08.027

18. Ivanov, V., Stabnikov, V., Stabnikova, O., Salyuk, A., Shapovalov, E., Ahmed, Z., Tay, J. H. (2019). Iron-containing clay and hematite iron ore in slurry-phase anaerobic digestion of chicken manure. AIMS Materials Science, 6 (5), 821-832. doi: https://doi.org/ 10.3934/matersci.2019.5.821

19. Markou, G. (2015). Improved anaerobic digestion performance and biogas production from poultry litter after lowering its nitrogen content. Bioresource Technology, 196, 726-730. doi: https://doi.org/10.1016/j.biortech.2015.07.067

20. Abouelenien, F., Kitamura, Y., Nishio, N., Nakashimada, Y. (2009). Dry anaerobic ammonia-methane production from chicken manure. Applied Microbiology and Biotechnology, 82 (4), 757-764. doi: https://doi.org/10.1007/s00253-009-1881-3

21. Abouelenien, F., Fujiwara, W., Namba, Y., Kosseva, M., Nishio, N., Nakashimada, Y. (2010). Improved methane fermentation of chicken manure via ammonia removal by biogas recycle. Bioresource Technology, 101 (16), 6368-6373. doi: https://doi.org/10.1016/ j.biortech.2010.03.071

22. Habibullin, R. E. (1995). Issledovanie i razrabotka intensivnoy biotehnologii anaerobnoy pererabotki kurinogo pometa. Kazan’, 18.

23. Shapovalov, V. B., Shapovalov, E. B., Zhadan, S. O., Saliuk, A. I. (2015). Pat. No. 105080. Sposib otrymannia biohazu ta dobryva z vidkhodiv z vysokym vmistom azotu. No. u201505811; declareted: 12.06.2015; published: 10.03.2016, Bul. No. 5. Available at: https://uapatents.com/3-105080-sposib-otrimannya-biogazu-ta-dobriva-z-vidkhodiv-z-visokim-vmistom-azotu.html

24. Saliuk, A. I., Shapovalov, E. B., Shapovalov, V. B., Zhadan, S. O. (2016). Pat. No. 114655. Sposib oderzhannia tverdoho mineralnoho dobryva pry metanoviy fermentatsiyi. No. u 201610452; declareted: 17.10.2016; published: 10.03.2017, Bul. No. 5. Available at: https://uapatents.com/5-114655-sposib-oderzhannya-tverdogo-mineralnogo-dobriva-pri-metanovijj-fermentaci.html 
25. Crolius, S. H. (2018). IHI First to Reach 20\% Ammonia-Coal Co-Firing Milestone. Ammonia Energy Association. Available at: https://www.ammoniaenergy.org/articles/ihi-first-to-reach-20-ammonia-coal-co-firing-milestone/

26. Salyuk, A., Zhadan, S., Shapovalov, E., Tarasenko, R. (2017). Methane fermentation of chicken manure under conditions of reduced concentration of inhibitors. Alternative Energy and Ecology, 4-6, 89-98. doi: https://doi.org/10.15518/isjaee.2017.04-06.089-098

27. Shapovalov, Ye., Zhadan, S., Salyuk, A., Kotinskiy, A. (2018). Regulation of the ammonia nitrogen concentration at the methane fermentation of chicken manure under conditions of the liquid phase recirculation. Scientific Works of NUFT, 24 (6), 65-72. doi: https://doi.org/10.24263/2225-2924-2018-24-6-10

28. Pratt, P. F., Castellanos, J. Z. (1981). Available nitrogen from animal manures. California Agriculture.

29. Vedeneev, A. G., Vedeneeva, T. A. (2006). Biogazovye tehnologii v Kyrgyzskoy respublike. Bishkek: Tipografiya «Evro», 90.

30. Brown, T. (2017). The new generation of fuel cells: fast, furious, and flexible. Ammonia Energy Association. Available at: https:// www.ammoniaenergy.org/articles/the-new-generation-of-fuel-cells-fast-furious-and-flexible/

31. Bartels, J. R. (2008). A feasibility study of implementing an ammonia economy. Iowa State University. doi: https://doi.org/ 10.31274/etd-180810-1374

32. Ammonia fuel. Gencell. Available at: https://www.gencellenergy.com/gencell-technology/ammonia-fuel/

33. Ammonia-Fueled Gas Turbine Power Generation (2017). Ammonia Energy Association. Available at: https://www.ammoniaenergy. org/articles/ammonia-fueled-gas-turbine-power-generation/

34. Ito, S., Uchida, M., Onishi, S., Kato, S., Fujimori, T., Kobayashi, H. (2018). Performance of Ammonia - Natural Gas Co-Fired Gas Turbine for Power Generation. 2018 AIChE Annual Meeting. Available at: https://www.aiche.org/conferences/aiche-annualmeeting/2018/proceeding/paper/549b-performance-ammonia-natural-gas-co-fired-gas-turbine-power-generation

35. Crolius, S. H. (2019). The Evolving Context of Ammonia-Coal Co-Firing. Ammonia Energy Association. Available at: https://www. ammoniaenergy.org/articles/the-evolving-context-of-ammonia-coal-co-firing/

36. Brown, T. (2018). Ammonia for Power: a literature review. Ammonia Energy Association. Available at: https://www.ammoniaenergy. org/articles/ammonia-for-power-a-literature-review/

37. Grannell, S. M., Assanis, D. N., Bohac, S. V., Gillespie, D. E. (2006). The Operating Features of a Stoichiometric, Ammonia and Gasoline Dual Fueled Spark Ignition Engine. Energy Conversion and Resources. doi: https://doi.org/10.1115/imece2006-13048

38. Grannell, S. M., Assanis, D. N., Bohac, S. V., Gillespie, D. E. (2008). The Fuel Mix Limits and Efficiency of a Stoichiometric, Ammonia, and Gasoline Dual Fueled Spark Ignition Engine. Journal of Engineering for Gas Turbines and Power, 130 (4). doi: https:// doi.org/10.1115/1.2898837

39. $\mathrm{NH}_{3}$ Car. $\mathrm{NH}_{3} \mathrm{CAR}$. Available at: http://nh3car.com/

40. Reiter, A. J., Kong, S.-C. (2011). Combustion and emissions characteristics of compression-ignition engine using dual ammoniadiesel fuel. Fuel, 90 (1), 87-97. doi: https://doi.org/10.1016/j.fuel.2010.07.055

41. Reiter, A. J., Kong, S.-C. (2008). Demonstration of Compression-Ignition Engine Combustion Using Ammonia in Reducing Greenhouse Gas Emissions. Energy \& Fuels, 22 (5), 2963-2971. doi: https://doi.org/10.1021/ef800140f

42. Frigo, S., Gentili, R. (2013). Analysis of the behaviour of a 4-stroke Si engine fuelled with ammonia and hydrogen. International Journal of Hydrogen Energy, 38 (3), 1607-1615. doi: https://doi.org/10.1016/j.ijhydene.2012.10.114

43. Liu, R., Ting, D. S.-K., Checkel, M. D. (2003). Ammonia as a fuel for SI engine. SAE Technical Papers. doi: https://doi.org/ 10.4271/2003-01-3095

44. SIP Energy Carriers - The Innovation for Ammonia Fuel in Japan. Available at: https://www.youtube.com/watch?v=5ejL65tKsGM

45. Crolius, S. H. (2018). Direct Ammonia Fuel Cells Take Another Step Forward in Japan. Ammonia Energy Association. Available at: https://www.ammoniaenergy.org/articles/direct-ammonia-fuel-cells-take-another-step-forward-in-japan/

46. Technology. Hydrofuel. Available at: https://www.nh3fuel.com/index.php/technology/18-engine-conversions

47. Kelly-Detwiler, P. (2020). A Key To The 'Hydrogen Economy' Is Carbon-Free Ammonia. Forbes. Available at: https://www.forbes. $\mathrm{com} /$ sites/peterdetwiler/2020/12/16/maybe-the-hydrogen-economy-will-become-the-ammonia-economy/?sh=4453f9e64936

48. Dolan, R. H., Anderson, J. E., Wallington, T. J. (2021). Outlook for ammonia as a sustainable transportation fuel. Sustainable Energy \& Fuels, 5 (19), 4830-4841. doi: https://doi.org/10.1039/d1se00979f

49. Hansson, J., Brynolf, S., Fridell, E., Lehtveer, M. (2020). The Potential Role of Ammonia as Marine Fuel - Based on Energy Systems Modeling and Multi-Criteria Decision Analysis. Sustainability, 12 (8), 3265. doi: https://doi.org/10.3390/su12083265

50. Fuchs, W., Wang, X., Gabauer, W., Ortner, M., Li, Z. (2018). Tackling ammonia inhibition for efficient biogas production from chicken manure: Status and technical trends in Europe and China. Renewable and Sustainable Energy Reviews, 97, 186-199. doi: https://doi.org/10.1016/j.rser.2018.08.038

51. Shapovalov, Y., Zhadan, S., Bochmann, G., Salyuk, A., Nykyforov, V. (2020). Dry Anaerobic Digestion of Chicken Manure: A Review. Applied Sciences, 10 (21), 7825. doi: https://doi.org/10.3390/app10217825

52. Plyatsuk, L., Chernish, E. (2014). Intensification of Anaerobic Microbiological Degradation of Sewage Sludge and Gypsum Waste Under Bio-Sulfidogenic Conditions. The Journal of Solid Waste Technology and Management, 40 (1), 10-23. doi: https://doi.org/ $10.5276 /$ jswtm.2014.10

53. Niu, Q., Qiao, W., Qiang, H., Hojo, T., Li, Y.-Y. (2013). Mesophilic methane fermentation of chicken manure at a wide range of ammonia concentration: Stability, inhibition and recovery. Bioresource Technology, 137, 358-367. doi: https://doi.org/10.1016/j.biortech.2013.03.080

54. Saliuk, A. I., Zhadan, S. O., Shapovalov, Ye. B., Tarasenko, R. A. (2016). Inhibuvannia vyrobnytstva metanu z kuriachoho poslidu amoniynym azotom. Vidnovliuvana Enerhetyka, 1, 79-83.

55. Pozin, M. E. (1974). Tehnologiya mineral'nyh soley: Udobreniy, pesticidov, promyshlennyh soley, okislov i kislot. Leningrad: Himiya, 792.

56. Klevke, V. L., Polyakov, N. N., Arsen'eva, L. Z. (1956). Tehnologiya azotnyh udobreniy. Moscow, 290. 